\title{
The Impact of Customer Relationship Management on Organization Profit of in Somali
}

\section{Waskito KS*}

Department of Management Science, Pasundan University, Indonesia

\begin{abstract}
The purpose of this study to investigate the impact of customer relationship management on the profit of organization in Somali. The study used the domestic theory to analyze data by applying statistical package for social science (SPSS version 20.0) special regression model tool was used our study. The results The CRM are high influence Organization profit, so that CRM was the responsible employee retention. Somali businesses have not use Management information system. Also the researcher finding Somali full capacity internet. Also the researcher finding Somali have not use e-commerce, the reason the people have not knowledge Online Business and mostly citizen have not master card or credit card. The main objective of the study to investigate the effect of CRM on the profit of organization in Somali and to explore the CRM important of business in Somali. Also the researcher finding Somali have not use e-commerce, the reason the people have not knowledge Online Business and mostly citizen have not master card or credit card. Somalia companies have not department of CRM to keep customer satisfaction and luck of Management information system.
\end{abstract}

Keywords: Customer relationship management system; Profit; Business; Organization

\section{Introduction}

Modern marketing shows for more developing and increase profitability of organization to produce good product, then attractive the whole of customer, the only way to get beneficial customer, marking relationship.

Although the customer was dived two part internal customer and external customer, the internal customer is employee of company so that employee partially is asset of organization because the organization depend on, the organizing must keep morality of their employee if they do not keep the productively become low so that the company must mark policy to improve their employee and motivation then training to increase their talent and skills, that is double benefit of organization and employee, because they increase their productivity.

External customer is buyers the buyers they buy of organization, so that organization must the collect date relating their customer, in fortunately Somali Company have not management information system that reason was responsible luck of good customer relationship.

Profit is a financial benefit that is realized when the amount of revenue gained from business work reduce the expanses, and also say the profit when total sales revenue is greater than total cost, for example the total sales of Geele general trading company was $\$ 100,000$ and the total cost was $\$ 75,000$ so that the researcher say the profit of this Geele general trading company become $\$ 25,000$. The researcher justify the amount of profit of this company comes total sales reduce total cost to gain profit of company if the amount of sales was greater than the amount of cost the amount gain we called profit, if the amount of sales is less than the amount of cost we called loss and if they same we called breakeven point means no gain no loss.

\section{Problem Statement}

These days Somali were come disbar and they marked a lot of investment and increase economy, so they created small business and projects mostly they establish hotel like peach view restaurant they arise level of completion of the business, and also increase high level of customer turnover, furthermore increase customer acquisition, cost and growing customer expectation. There for most of Somali business have not focus on Customer relationship management system and finally the problem of this study seeks to show the relationship between customer relationship management system performances of organizational in Somali business.

\section{Objective of the Study}

- To investigate the impact CRM on benefit of business in Somali.

- To explore the CRM important of business in Somali.

\section{Scope of the study}

The study was exploring the impact Customer relationship management on the profit of organization in Somali.

\section{Review of Literature}

\section{Customer relationship management}

According to Russell et al. [1] customer relationship management is the new Intonation of marketing. Businesses like Oracle have come up with services and products and keyword Customer relationship management system and profit.

Modern marketing shows for more developing and increase profitability of organization to produce good product, then attractive the whole of customer, the only way to get beneficial customer, marking relationship.

Although the customer was dived two part internal customer and external customer, the internal customer is employee of company so that employee partially is asset of organization because the organization

*Corresponding author: Waskito KS, Department of Management Science Pasundan University, Indonesia, Tel: +62 22 2021440; E-mail: saptonokw@yahoo.com

Recieved November 21, 2017; Accepted December 28, 2017; Published January 05,2018

Citation: Waskito KS (2018) The Impact of Customer Relationship Management on Organization Profit of in Somali. J Entrepren Organiz Manag 7: 221. doi: 10.4172/2169-026X.1000221

Copyright: (c) 2018 Waskito KS. This is an open-access article distributed unde the terms of the Creative Commons Attribution License, which permits unrestricted use, distribution, and reproduction in any medium, provided the original author and source are credited. 
depend on, the organizing must keep morality of their employee if they do not keep the productively become low so that the company must mark policy to improve their employee and motivation then training to increase their talent and skills, that is double benefit of organization and employee, because they increase their productivity.

External customer is buyers the buyers they buy of organization, so that organization must the collect date relating their customer, in fortunately Somali Company have not management information system that reason was responsible luck of good customer relationship.

Profit is a financial benefit that is realized when the amount of revenue gained from business work reduce the expanses, and also say the profit when total sales revenue is greater than total cost, for example the total sales of Geele general trading company was $\$ 100,000$ and the total cost was $\$ 75,000$ so that the researcher say the profit of this Geele general trading company become $\$ 25,000$. The researcher justify the amount of profit of this company comes total sales reduce total cost to gain profit of company if the amount of sales was greater than the amount of cost the amount gain we called profit, if the amount of sales is less than the amount of cost we called loss and if they same we called break- even point means no gain no loss.

According to Al-Azzam [2] he says the customer relationship management First and leading, to form customer-oriented behaviors, organizations have to improve a suitable working environment for service in work. For example, giving staff with the current tools, and technology, customer satisfaction pursuing and complaints management systems, moving leadership, and right rewards systems can all make these behaviors [3].

Therefore, the achievement of CRM close depends on the vigorous involvement of the employees in the organization them self [4-6]. In finish, the customer-orientation strategy is one of an organization's resources to increase customer satisfaction and business income and is also a very significant measurement.

\section{Profit}

According to McMichael et al. [7] he say the main profit of organization to gain customer relationship more sales revue increase level of productivity and also have more business values like reduce direct marketing cost because when use the customer relationship management can easily know customer data if they complain or mark order and so help to contact and keep their relationship and attractive new customer, and increase customer satisfaction, then used the churn rate, the customer churn reduce as sales, service and marketing better respond to customer needs so that is measurement number of customer who stop using or purchasing product or service from the organization.

That can track customers through the World Wide Web and be able to forecast their forward moves wants and needs.

According Kotler et al. [8] he says the uses customer relationship management can changeable with customer relationship marketing. He says these CRM aim is to produce high excellence equity which he called customer equity. According Hogan et al. [9] further differentiates the three sectors of customer equity, relationship equity, brand equity and value equity.

Researchers argue that CRM cannot be effective even if the organizations enjoy the most modern technology and adapt a customer oriented way, unless the project is finally integrated by them [10]. Further, as a confirmation for this point, Fan and $\mathrm{Ku}$ [11] stresses that CRM success requires effective service and suitable operation procedures, rather than only technological systems.

According to Al-Azzam [2], he says the customer relationship management First and leading, to form customer-oriented behaviors, organizations have to improve a suitable working environment for service in work. For example, giving staff with the current tools, and technology, customer satisfaction pursuing and complaints management systems, moving leadership, and right rewards systems can all make these behaviors [3]. Therefore, the achievement of CRM close depends on the vigorous involvement of the employees in the organization them self [4-6]. In finish, the customer orientation strategy is one of an organization's resources to increase customer satisfaction and business income and is also a very significant measurement.

\section{The importance of CRM to an organization}

The primary focus of any CRM strategy is to empower the organization to generate and retain profitable customers that help the organization [12]. Most strategies advance around three features, specifically, customer acquisition, customer profitability and customer profitability, due to the reduced costs linked with retaining customers rather than obtaining new.

\section{Customer profitability}

Customer profitability tracks the monetary performance of businesses with respect to all the costs related with a business [13]. Profitability is strong-minded in the light of the generation value of the purchaser to the organization, pleasing into account the income and expenses associated with each customer over time. The tracking of profitability is made more accurate through the use of technology.

The evaluation of Customer relationship management itself is not a new idea but is now applied due to recent fees in initiative software technology. A result of sales force robotics (SFA) tools, CRM is often referred to in the literature as one-to-one ad varnishing [14]. SFA software automates routine tasks such as tracking customer.

Although one of the most actual ways to exploit sales revenue opportunities is by optimizing the advertising mix. But in instruction to do that, marketing sections need end-to-end perceptibility into marketing data through a united CRM application and this application work online needs internet so that Somalia have not tool like enterprise system and whole of management information system.

\section{Benefits of CRM}

The following lists of wanted CRM benefits were collected and short from an extensive survey of fresh CRM lessons [15].

Improved ability to target profitable customers, integrated offerings across channels and improved sales force efficiency and effectiveness; There is mutual relationship department of sales, supporters and marketing like this shape and this figure illustrate customer relationship management are contact sales are and center call and marketing so the CRM were reduce direct cost of marketing, but Somali Business mostly they use Radio advertising and TV, as while as this year 2017 are increase number of firms use social Media like face book to show their product and service into community, which help to reduce direct advertising cost [16-19] (Figure 1).

\section{Research Methodology}

\section{Sample size}

The sample frame of the research refers to the individuals of the 
Citation: Waskito KS (2018) The Impact of Customer Relationship Management on Organization Profit of in Somali. J Entrepren Organiz Manag 7: 221. doi: 10.4172/2169-026X.1000221

Page 3 of 4

total population to Be questioned, thus, the sample size of this research was be 35 respondents including both lower and Higher staff, besides, the researcher was choose this sample size based on the observation that the sample of $(30 \mathrm{ml})$ and above is enough to make inference about the entire Population [20,21].

\section{Sample procedure}

The sampling procedure that the researcher was use in this study was being non-probability sampling.

Expressly, convenience sampling technique was be used and this technique is intended.

To solicit information from the respondents who are available and wising to take division in the Study. Non-probability sampling of researcher.

Is a sampling procedure in which the individual members of the population have not equal chance to select?

Although research instrument, this study was employ questionnaire tool to collect data from the respondents and therefore the Researchers was utilizing developed questionnaire. The researchers were developing a questionnaire.

\section{Result and Discussion}

In the following table, descriptive analysis shows the Mean. Value stands highest average and standard deviation (Table 1).

The researcher shows this descriptive statistics the number of responded and show the stand division (Table 2).

This model illustrate the influence of CRM of the profit of organization so that shows R square (0.322), and so Adjust R Square
(0.146), this study researcher was get profit of organization high impact the CRM. Shows there is no CRM in Somali.

\section{Main finding}

The CRM are high influence Organization profit, so that CRM was the responsible employee retention. Somali businesses have not use Management information system.

Also the researcher finding Somali have not full capacity internet.

Also the researcher finding Somali have not use e-commerce, the reason the people have not knowledge Online Business and mostly citizen have not master card or credit card.

Somalia companies have not department of CRM to keep customer satisfaction and luck of Management information system.

\section{Conclusion}

This study has investigated the effect CRM on the profit of organization in Somali for the period which spanned last 10 years, the researcher use regression model tool was used our study, found the CRM are high influence organization in Somali.

The objective was to investigate the impact CRM on benefit of business in Somali.

To explore the CRM important of business, Somalia companies have not department of CRM to keep customer satisfaction.

The author recommends the organizations select right workers then provide courses relate CRM I recommends to establish any origination department of CRM.

The author recommends establishing Management information system.

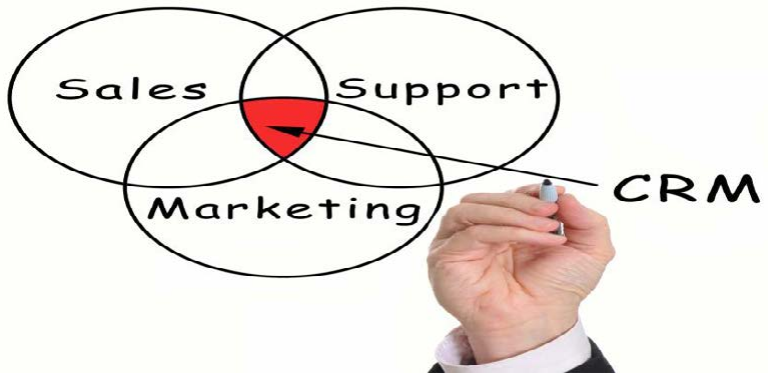

Figure 1: Customer relationship management.

\begin{tabular}{|c|c|c|c|c|c|c|}
\hline & \multirow{2}{*}{$\frac{\mathbf{N}}{\text { Statistic }}$} & \multirow{2}{*}{$\begin{array}{c}\text { Minimum } \\
\text { Statistic }\end{array}$} & \multirow{2}{*}{$\begin{array}{c}\text { Maximum } \\
\text { Statistic }\end{array}$} & \multicolumn{2}{|c|}{ Mean } & \multirow{2}{*}{$\begin{array}{c}\text { Std. Deviation } \\
\text { Statistic }\end{array}$} \\
\hline & & & & Statistic & Std. Error & \\
\hline Gender & 35 & 1.00 & 2.00 & 1.2857 & .07748 & .45835 \\
\hline Age & 35 & 1.00 & 2.00 & 1.7143 & .07748 & .45835 \\
\hline Status & 35 & 1.00 & 3.00 & 1.7429 & .08543 & .50543 \\
\hline Experience & 35 & 1.00 & 3.00 & 1.8857 & .12815 & .75815 \\
\hline education & 35 & 1.00 & 4.00 & 2.2286 & .10913 & .64561 \\
\hline Valid N (list wise) & 35 & & & & & \\
\hline
\end{tabular}

Table 1: Descriptive statistics.

\begin{tabular}{|c|c|c|c|c|c|c|c|c|c|c|}
\hline \multirow[t]{2}{*}{ Model } & \multirow[t]{2}{*}{$\mathbf{R}$} & \multirow[t]{2}{*}{ R Square } & \multirow{2}{*}{$\begin{array}{l}\text { Adjusted R } \\
\text { Square }\end{array}$} & \multirow{2}{*}{$\begin{array}{l}\text { Std. Error of } \\
\text { the Estimate }\end{array}$} & \multicolumn{5}{|c|}{ Change Statistics } & \multirow{2}{*}{$\begin{array}{l}\text { Durbin- } \\
\text { Watson }\end{array}$} \\
\hline & & & & & $\begin{array}{c}\text { R Square } \\
\text { Change }\end{array}$ & F Change & df1 & df2 & Sig. F Change & \\
\hline 1 & .568 & .322 & .146 & 1.05918 & .322 & 1.833 & 7 & 27 & .122 & 2.685 \\
\hline
\end{tabular}


Citation: Waskito KS (2018) The Impact of Customer Relationship Management on Organization Profit of in Somali. J Entrepren Organiz Manag 7: 221. doi: 10.4172/2169-026X.1000221

\section{References}

1. Russell S, Norvig P, Intelligence A (1995) Artificial Intelligence, A modern approach. Prentice-Hall, Englewood Cliffs, pp: 25-27.

2. Al-Azzam MFA (2016) The Impact of Customer Relationship Management on Hotels Performance in Jordan. International Journal of Business and Social Science.

3. Mechinda P, Patterson PG (2011) The impact of service climate and service provider personality on employees' customer-oriented behavior in a highcontact setting. The Journal of Services Marketing 25: 101-113.

4. Boulding W, Staelin R, Ehret M, Johnston WJ (2005) A customer relationship management roadmap: what is known, potential pitfalls, and where to go. Journal of Marketing 69: 155-166.

5. Payne A, Frow $P$ (2006) Customer relationship management: from strategy to implementation. Journal of Marketing Management 22: 135-168.

6. Tamilarasan R (2011) Customer Relationship Management in Banking Services. Journal of Advances in Management.

7. McMichael GA, Rakowski CL, James BB, Lukas JA (2005) Estimated fal Chinook salmon survival to emergence in dewatered redds in a shallow side channel of the Columbia River. North American Journal of Fisheries Management 25: 876-884.

8. Kotler M, Stryjer R, Strous RD, Shaked G, Bar F, et al. (2003) Amantadine as augmentation therapy in the management of treatment-resistant depression. International Clinical Psychopharmacology 18: 93-96.

9. Hogan JE, Lemon KN, Rust RT (2002) Customer equity management: Charting new directions for the future of marketing. Journal of Service Research 5: 4-12.

10. Sin LY, Alan CB, Heung VC, Yim FH (2005) An analysis of the relationship between market orientation and business performance in the hotel industry. International Journal of Hospitality Management 24: 555-577.
11. Fan YW, Ku E (2010) Customer focus, service process fit and customer relationship management profitability: the effect of knowledge sharing.The Service Industries Journal 30: 203-223.

12. Ngai EWT (2005) Customer relationship management research (1992-2002) An academic literature review and classification. Marketing Intelligence \& Planning 23: 582-605.

13. Gordon I (1998) Relationship marketing: New strategies, techniques, and technologies to win the customers you want and keep them forever. Wiley.

14. Peppers D, Rogers M, Dorf B (1999) Is your company ready for one-to-one marketing?

15. Keith N, Frese M (2008) Effectiveness of error management training: a metaanalysis. Journal of Applied Psychology 93: 59-69.

16. Catalan-Matamoros D (2011) An Overview to Customer Relationship Management.

17. Chen JI, Popovich K (2008) Understanding customer relationship management (CRM): People, process and technology. Business Process Management Journal 9: 672-688.

18. Khalid K, Salim MH, Loke PS (2011) The Impact of Rewards and Motivation on Job Satisfaction in Water Utility Industry. International Conference on Financia Management and Economics IPEDR 11: 35-41.

19. Viljoen M, Bennett JA, Berndt AD, Van Zyl CR (2005) The use of technology in customer relationship management (CRM). Acta Commercii 5: 106-116.

20. Fozia NR, Shiamwama MS, Otiso NK (2014) Impact of Customer Relationship Management as a Strategy for Competitive Advantage in Kenyan Public Universities: A Case Study of Moi University. International Journal of Business Humanities and Technology.

21. Sadek H, Tantawi $P$ (2004) Measuring customer relationship managemen (CRM) and its relationship with customer satisfaction in the Egyptian Banking Sector, pp: 1-14 